\title{
Bangunan Ilmu Politik Hukum diantara Ilmu-ilmu Sosial dan Ilmu Hukum
}

\author{
Indriyana Dwi Mustikarini \\ Fakultas Hukum, Universitas PGRI Madiun, Jl. Setia Budi No. 85, Madiun, 63118 \\ E-mail: indriyanadwimustikarini@unipma.ac.id
}

\begin{abstract}
This paper aims to describe the Building of Legal Political Science between Social Sciences and Legal Studies in Indonesia. This research focuses on the study of the legal, political science of other social sciences. The method used in this research is normative juridical. This method examines the applicable laws and regulations as well as theoretical from a variety of literature, relating to the politics of law in the formation of legislation. The results of this study indicate the relationship between law and political science that law is determined by politics, so the law is formed based on expectations or what should be (das sollen). Instead of politics determined by law, the law was formed by agreement of the political elite / actual reality (das sein). While law and politics are interdependent, the law is developed based on what should be and actual reality (das Sollen-Sein).
\end{abstract}

Keywords - : legal politics; legal science; political science.

\section{PENDAHULUAN}

Indonesia, dari data Webershandwick, memiliki 65 juta pengguna Facebook aktif, dan 33 juta pengguna aktif setiap harinya, 55 juta pengguna menggunakan ponsel untuk mengakses per bulan dan 28 juta menggunakan ponsel untuk mengakses per harinya. Beberapa kasus yang berkaitan dengan Undang-Undang (yang selanjutnya dsingkat UU) Informasi dan Transaksi Elektronik (yang selanjutnya disingkat ITE), yang pernah terjadi di Indonesia misalnya kasus Prita Mulyasari dan kasus Baiq Nuril yang menyita perhatian publik.

Kedudukan ilmu politik hukum seringkali menimbulkan perdebatan antara ilmu politik dan ilmu hukum. Negara menjadi objek kajian dalam Ilmu Politik dan Ilmu Hukum. Negara didirikan harus memiliki unsur-unsur negara meliputi rakyat, wilayah dan pemerintahan yang memiliki kedaulat. Pemerintahan yang berdaulat didahului dengan kekuasaan baik kekuasaan untuk diperintah maupun memerintah. Politik dan kekuasaan yang merupakan kajian ilmu politik yang sangat dekat sekali. Dengan kekuasaan orang dapat menggerakkan orang lain tentu saja dengan ilmu politik.

Berbeda dengan ilmu politik, hukum merupakan alat untuk mewujudkan kekuasaan. Hukum positif yang diberlakukan pada satu negara berisi baik ide, gagasan maupun cita-cita serta keadilan dan kepastian yang mengatur hubungan antara indvidu dengan individu, individu dengan lingkungan masyarakat, individu dengan negara dan negara terhadap masyarakat Pemberlakuan hukum positif yang berbentuk peraturan perundang-undangan tersebut merupakan wujud pelaksanaan politik. Pelaksanaan peraturan yang dibuat oleh negara merupakan cara negara dalam mewujudkan suatu tujuan suatu dari negara tersebut.

Masyarakat mentaati dan melaksanakan peraturan perundang-undangan bahwa hukum berfungsi a tool of social engineering mengandung makna ${ }^{1}$ bahwa perubahan yang telah direncanakan maka kontrol berada di bawah pelopor pengusul perubahan tersebut. Sebagaimana yang dikemukakan Zaeni Asyhadie ${ }^{2}$ bahwa hukum berfungsi a tool of social engineering digunakan untuk mengatur kehidupan berbangsa dan bernegara guna mewujudkan yang menjadi tujuan yang telah dicita-citakan.

Satjipto Rahardjo mengatakan hukum sebagai Social Engineering merupakan kesadaran mengimplementasi hukum untuk mewujudkan ketertiban dalam masyarakat yang diharapkan atau melakukan perubahan dalam yang dicita-citakan. Perubahan ini menjadikan hukum modern akan berhadapan dengan hukum tradisional. ${ }^{3}$

Soemarno Partodihardjo mengemukakan bahwa hukum merupakan konsep law as a tool social engineering maka seperti halnya yang dikemukan Roscoe Pound, bahwa hukum dijadikan faktor penggerak perubahan di dalam masyarakat yang lebih baik dari sebelumnya. Dengan demikian sejalan dengan fungsi-fungsi hukum tersebut sehingga dalam mewujudkan perubahan hendaknya harus direncanakan secara terukur dan sistematis supaya tujuan dari perubahan yang dikehendaki menjadi perubahan yang lebih baik. ${ }^{4}$

Dengan demikian bahwa peraturan yang ada dalam suatu negara yang diberlakukan digunakan sebagai acuan untuk mewujudkan masyarakat berdasarkan tujuan negara yang telah ditetapkan. Politik dan hukum mempunyai peranan serta tugas

\footnotetext{
${ }^{1}$ Said Sampara dkk, Buku Ajar Pengantar Ilmu Hukum, Total Media, Yogyakarta, 2011, hlm. 68

${ }^{2}$ Arief Rahman dkk, Pengantar Ilmu Hukum, Rajawali Pers, Jakarta, 2016, hlm. 126

${ }^{3}$ Satjipto Rahardjo, Hukum dan Perubahan Sosial (Suatu Tinjauan Teoritis Serta Pengalaman-pengalaman di Indonesia), Genta, Yogyakarta, 2009, hlm. 128

${ }^{4}$ Soemarno Partodihardjo, Tentang Keterbukaan Informasi Publik. Gramedia, Jakarta, 2009, hlm. 147
} 
yang saling keterkaitan yang masing-masing memiliki fungsi dan peranan yang berbeda. Dari uraian latar belakang di atas maka, terdapat permasalahan bagaimanakah Bangunan Ilmu Politik Hukum diantara Ilmu-ilmu Sosial dan Ilmu Hukum ?

\section{METODE PENELITIAN}

Penelitian ini menggunakan penelitian yuridis normatif. Yang dimaksud dengan penelitian yuridis normatif merupakan penelitian hukum kepustakaan. Penelitian hukum yang dilakukan dengan cara meneliti bahan pustaka atau data hanya datadata sekunder ${ }^{5}$. Peter M. Marzuki juga mengemukakan penelitian hukum (legalresearch) normatif merupakan penelitian yang menemukan kebenaran koherensi. Yang dimaksud kebenaran koherensi merupakan aturan hukum yang berdasarkan norma hukum maupun norma yang berisi perintah maupun larangan berdasarkan prinsip hukum, serta tindakan seseorang sesuai dengan norma hukum (bukan hanya sesuai aturan hukum) atau berdasarkan prinsip hukum. ${ }^{6}$

\section{III.HASIL PENELITIAN DAN PEMBAHASAN}

\section{Cakupannya Ilmu Politik Hukum Sebagai Teori}

Politik hukum merupakan istilah dalam hukum Belanda rechtspolitiek. Istilah ini merupakan gabungan dari kata recht dan politiek. Recht artinya hukum dalam bahasa Indonesia sedangkan politiek artinya politik. Menurut Hence van Maarseven, politiekrecht gabungan 2 kata yang memiliki konotasi yang berbeda. ${ }^{7}$ Polis memiliki arti city state merupakan Bahasa Yunani. Pengabdopsian polis menjadi politik dalam Bahasa Indonesia merupakan segala sesuatu yang berhubungan dengan negara. ${ }^{8}$ Rod Hague mengemukakan bahwa politik merupakan kegiatan kelompok untuk mencapai keputusan kolektif yang mengikat meskipun berupaya untuk mendamaikan perbedaan di antara anggota mereka. Sedangkan Andrew Heywood, Politik merupakan kegiatan yang dilakukan suatu negara yang memiliki tujuan negara dengan membuat peraturan, mempertahankan peraturan serta merubah pertauran yang kadang menimbulkan konflik dan kerja sama. ${ }^{9}$

Berdasarkan uraian di atas, politik adalah sesuatu hal yang berkaitan pengambilan keputusan, kebijakan pada suatu negara untuk mendapatkan kehidupan yang lebih baik serta untuk menpertahankan kekuasaan. Sedangkan hukum menurut Utrecht dalam Zaeni Asyhadie merupakan sekumpulan peraturan yang berisi perintah dan larangan oleh pihak yang berwenang sehingga sekumpulan peraturan perundang-undangkan tersebut ditaati. ${ }^{10}$ Hukum menurut Hamaker bukan keseluruhan peraturan yang menetapkan seseorang harusnya bertindak berdasarkan peraturan yang mengatur tingkah laku individu dalam hidup bermasyarakat. ${ }^{11}$ Dengan demikian hukum adalah seperangkat aturan yang bersifat memaksa dengan sanksi yang tegas dan dibuat oleh penguasa negara.

Mahfud MD berpendapat bahwa politik hukum adalah garis kebijakan yang digunakan acuan untuk pembuatan dan pelaksanaan hukum untuk mewujudkan tujuan negara. Bisa dikatakan bahwa politik hukum merupakan cara untuk mencapai tujuan negara dengan melalui pelaksanaan hukum. ${ }^{12}$ Abdul Latif berpendapat ${ }^{13}$ bahwa politik hukum sebagai bagian ilmu hukum yang mengkaji perubahan peraturan hukum yang sedang diberlakukan kemudian setelah dikaji maka ditentukan hukum yang dimaksud beserta tujuan dalam upaya untuk mewujudkan tujuan perubahan di dalam kehidupan masyarakat sebagai hukum yang diharapkan untuk masa yang akan datang (ius constituendum). Sedangkan Said Sampara dkk berpendapat bahwa politik hukum adalah ilmu yang mempelajari tentang harus diadakannya hukum yang baru sehingga hukum dapat memenuhi kebutuhan masyarakat yang digunakan sebagai alat untuk mengarahkan masyarakat demi terciptanya tujuan hukum yang dicitacitakan. $^{14}$

Berkaitan dengan definisi tersebut maka teori politik hukum (politiekrecht) merupakan legal policy (arah kebijakan hukum) yang akan diberlakukan oleh suatu negara guna mewujudkan tujuan negara. Adapun proses perwujudan tujuan negara dengan cara pembuatan peraturan hukum baru dan kemudian selanjutnya mengganti hukum lama. Dengan demikian politik hukum Indonesia harus mengacu pada tujuan negara dengan menggunakan sistem hukum yang digunakan di Indonesia mendasarkan pada Pembukaan UUD 1945 alenia 4, dan Pancasila dijadikan kaidah-kaidah dalam pembentukan hukum di Indonesia.

James E. Anderson mengemukakan kebijakan merupakan serangkaian perbuatan yang memiliki tujuan kemudian diikuti serta dilakukan oleh seorang maupun sekelompok untuk menyelesaikan atau mencari jalan keluar dari permasalahan. Kebijakan yang dimaksudkan adalah kebijakan yang dikembangkan oleh pejabat pemerintah, antara lain kebijakan merupakan perbuatan yang memiliki tujuan tertentu, isi dari kebijakan berupa pola tindakan pejabat pemerintah, kebijakan pemerintah dapat berupa

\footnotetext{
${ }^{5}$ Soerjono Soekanto dan Sri Mamuji, Penelitian Hukum Normatif Suatu Tinjauan Singkat, RajaGrafindoPersada, Jakarta, 2010 , hlm.13-14.

${ }^{6}$ Peter Mahmud Marzuki, Penelitian Hukum, 2005, Edisi Revisi, Kencana Perdana Media Group, Jakarta, hlm .47

${ }^{7}$ Imam Syaukani dan A.Ahsin Thohari, Dasar-dasar Politik Hukum, Rajagrafindo Persada, Jakarta, 2004, hlm. 19

${ }^{8}$ Miriam Budiardjo, Dasar-dasar Ilmu Politik, Gramedia Pustaka Utama, Jakarta, 2010, hlm. 13

${ }^{9}$ Miriam Budiardjo, op.cit, hlm. 16

${ }^{10}$ Zaeni Asyhadie, Pengantar Ilmu Hukum, Rajagrafindo Persada, Jakarta, 2014, hlm. 20

${ }^{11}$ Van Apeldoorn, Pengantar Ilmu Hukum, Cetakan ke-34, Pradnya Praramita, Jakarta, 2011, hlm.18

${ }^{12}$ Moh. Mahfud MD, Membangun Politik Hukum Menegakkan Konstitusi, Rajawali Pers, Jakarta, hlm. 15

${ }^{13}$ Abdul Latif, Op.Cit. hlm. 12

${ }^{14}$ Said Sampara dkk, Op.Cit, hlm. 28
} 
berbuat sesuatu dan tidak berbuat sesuatu dan suatu kebijakan berdasarkan peraturan yang berlaku yang bersifat memaksa. ${ }^{15}$ Kebijakan negara dibuat untuk atau garis resmi yang dimaksud dalam memberlakukan hukum atau tidak memberlakukan hukum.

Selanjutnya, ilmu politik hukum tidak hanya berkaitan dengan arah (legal policy) yang resmi meliputi hukum yang akan diberlakukan di masa yang akan datang tetapi juga berkaitan dengan hal-hal yang berkaitan dengan arah resmi, antara lain politik yang melatarbelakangi hukum itu terbentuk, budaya hukum yang ada dalam masyarakat, dan permasalahan dalam penegakan hukum. Politik hukum merupakan salah satu faktor yang menyebabkan terjadinya dinamika di dalam masyarakat. Pemberlakuan ius constituendum menjadi ius constitutum yang baru memerlukan partisipasi seluruh masyarakat.

Konsep cakupan studi dalam politik hukum meliputi :

1. Garis resmi yang ditetapkan pemerintah dalam rangka mewujudkan tujuan suatu negara berkaitan hukum yang akan diberlakukan maupun hukum yang tidak diberlakukan;

2. Kondisi politik, perekonomian, sosial, maupun budaya dalam melatar belakangi terbentuknya hukum baru;

3. Penegakan hukum yang terjadi dalam masyarakat. ${ }^{16}$

Berdasarkan pengertian politik dan hukum di atas maka studi politik hukum meliputi 3 hal, antara lain :

a. Politik hukum yang mengandung pengertian kebijakan negara (garis resmi) berkaitan dengan hukum yang akan diberlakukan pada masa yang akan datang dan tidak diberlakukan dalam rangka mewujudkan tujuan suatu negara. Hukum yang diberlakukan dan tidak diberlakukan ini mengandung arti membuat yang baru dan kemudian mengganti yang lama. Hal ini hukum berkedudukan sebagai instrumen utama dalam mewujudkan tujuan suatu negara. Intisari pemikiran hukum sebagai Legal Policy, antara lain :

1) Cita-cita bangsa Indonesia antara lain mewujudkan masyarakat adil makmur berdasar Pancasila. Cita-cita luhur bangsa Indonesia tidak tercantum pada pembukaan UUD 1945 namun hanya bersifat filosofi yang terpatri dalam sanubari bangsa Indonesia.

2) Tujuan negara Indonesia termaktub dalam Pembukaan UUD 1945 Alenia 4 merupakan bagian dari staatsfundamentalnorms, antara lain melindungi bangsa Indonesia dari integrasi wilayah dan ideologi, mencerdaskan kehidupan bangsa Indonesia, memajukan kesejahteraan bagi bangsa Indonesia serta melaksanakan ketertiban dan perdamaiandunia.

3) Cita hukum bangsa Indonesia yang dapat dijumpai dalam Pancasila merupakan dasar dan tujuan hukum dengan lima sila yang tersusun sebagai satu kesatuan antara sila yang satu dengan sila yang lainnya dan memiliki bentuk hirarkis piramidal.

4) Sistem hukum Pancasila yang digunakan sebagai ideologi bangsa

Dalam sistem hukum Pancasila ini mengambil konsep prismatik. Konsep prismatik ini merupakan pengambilan nilainilai yang baik kemudian digabungkan yang disesuaikan perkembangan. Misalnya individualisme dan kolektifisme, negara agama dan negara sekuler, rechtstaat dan rule of law maka hukum digunakan sebagai alat (Pound) maupun hukum digunkana sebagai cermin (Savigny). Disamping itu Pancasila juga sebagai kaidah penuntun sebagai acuan dijadikan dasar penyusunan hukum yang melindungi bangsa dari perpecahan baik wilayah maupun ideologi, hidup berbangsa dan bernegara berdasarkan dengan demokrasi serta nomokrasi, menegakkan keadilan sosial dan menjunjung tinggisikap toleransi terhadap pemeluk agama yang beradab.

5) Konstitusi Indonesia yaitu UUD 1945, berisi tentang aturan yang fundamental penyelenggaraan negara serta pembagian kekuasaan, perlindungan HAM, prosedur merubah undang-undang, larangan melakukan perubahan sifat yang mendasar dalam undang-undang.

6) Program Legislasi Nasional (Prolegnas). Prolegnas digunakan sebagai pedoman dan pengendali/pengawas terhadap penyusunan peraturan perundang-undangan tingkat pusat yang membatasi lembaga yang berwenang membuat peraturan perundang-undangan. Pembuatan peraturan perundang-undangan di Indonesia harus berdasarkan prolegnas tidak hanya mengacu pada UUD Negara Republik Indonesia Tahun 1945, tetapi juga untuk memenuhi kebutuhan hukum di dalam masyarakat. Kebutuhan hukum di dalam masyarakat ini merupakan akibat kemajuan ilmu pengetahuan dan teknologi serta tuntutan reformasi. Prolegnas ini disusun oleh Pemerintah bersama DPR yang kemudian tertuang dalam keputusan Ketua DPR. Selanjutnya pengujian dapat melalui Mahkamah Konstitusi melalui judicial review.

7) Program Legislasi Daerah (Prolegda) sebagaimana dalam prolegnas, prolegda disusun dan ditetapkan sebagai perencanaan dan pembentukan peraturan daerah yang ditetapkan setiap tahun dan dituangkan dalam keputusan DPRD. Prolegda dibentuk supaya perda yang akan diberlakukan pada masyarakat memiliki harmonisasi hukum yang merupakan kesatuan sistem hukum nasional yang sejalan. Pemberikan gambaran tentang permasalahan di daerah serta mempercepat pembentukan perda berdasarkan skala prioritas. Hal ini dapat diuji konsistensinya oleh Mahkamah Agung melalui judicial review.

\footnotetext{
${ }^{15}$ James E. Anderson, Public Policy Making, Holt Rinehart and Winston, New York, Cetakan ke-3, 1984, hlm. 3

${ }^{16}$ Moh. Mahfud MD, Op.Cit, hlm.14
} 
b. Politik hukum sebagai produk politik mengandung pengertian bahwa hukum itu ada melalui suatu proses perdebatan/pergulatan antar elite politik yang terdiri dari bidang politik, ekonomi, sosial dan budaya. Politik Hukum sebagai Produk Pergulatan Politik, meliputi :

1) Undang-undang sebagai hukum yang berlaku di masyarakat tidak mungkin lahir dengan sendirinya.

2) Undang-undang sebagai produk politik karena pembentukannya melalui proses perdebatan, pergulatan serta persaingan kehendak-kehendak para elite politik melalui kompromi-kompromi politik.

3) Hukum merupakan kristalisasi nilai-nilai yang telah sejak lama hidup di dalam masyarakat hanya berlaku bagi negara yang menganutsistem hukum common law dan bukan negara yang menganut sisten hukum civil law yang mendasarkan pada undang-undang.

4) Politik sebagai produk hukum. Menurut Von Kirchmann bahwa hukum sebagai politik maka hukum yang telah disahkan dan diberlakukan di dalam masyarakat hanyalah merupakan sampah yang tidak ada artinya jika legislatif hanya membatalkan undang-undang karena keputusan politik. Apabila hukum dibentuk mendasarkan pada das sollen maka hukum sebagai produk politik tetapi politik sebagai produk hukum.

Indikator Sistem Politik ${ }^{17}$

\begin{tabular}{|l|l|}
\hline Konfigurasi Politik Demokrastis & Konfigurasi Politik Otoriter \\
\hline $\begin{array}{l}\text { Parlemen kuat serta partai politik yang kuat akan } \\
\text { menentukan arah maupun kebijakan negara. }\end{array}$ & $\begin{array}{l}\text { Parlemen dan partai politik yang lemah akan berada di } \\
\text { bawah kendali eksekutif. }\end{array}$ \\
\hline $\begin{array}{l}\text { Eksekutif (Pemerintah) merupakan lembaga yang } \\
\text { bersifat netral. }\end{array}$ & $\begin{array}{l}\text { Eksekutif (pemerintah) menjadi lembaga yang tidak } \\
\text { netral dan intervensionis. }\end{array}$ \\
\hline $\begin{array}{l}\text { Adanya kebebasan pers, tanpa adanya sensor dan } \\
\text { pemberedelan. }\end{array}$ & Tidak adanya kebebasan pers. \\
\hline Pers bebas, tanpa sensor dan pemberedelan. & $\begin{array}{l}\text { Pers terbatas ruang geraknya karena ada ancaman } \\
\text { sensor dan pemberedelan. }\end{array}$ \\
\hline
\end{tabular}

Indikator Karakter Produk Hukum ${ }^{\mathbf{1 8}}$
\begin{tabular}{|l|l|}
\hline Karakter Produk Hukum Responsif & Karakter Produk Hukum Ortodoks \\
\hline Adanya partisipatif dalam pembuatan hukum & Pembuatan hukum lebih sentralistik dan dominatif \\
\hline Materi muatan mencerminkan aspiratif & Materi muatannya Positivst-instrumentalistik \\
\hline Produk hukum yang dihasilkan isinya limitatif & Produk hukum ortodoks isinya open interpretative \\
\hline
\end{tabular}

Dengan demikian hukum yang mendasarkan pada das sollen atau das sein maka tidak ada penentuan antara hukum dan politik. Oleh sebab itu sistem atau konfigurasi politik akan mewarnai hukum yang dihasilkan dengan karakter hukum tertentu.

a) Hubungan antara ilmu politik hukum dengan ilmu pengetahuan

Hubungan antara ilmu politik hukum dengan ilmu pengetahuan yang lainnya maka dalam hal ini berkaitan dengan pohon ilmiah hukum. Politik hukum merupakan bagian dari ilmu hukum. Ilmu hukum yang dimaksud yaitu hukum tata negara. Mahfud MD mengemukakan ${ }^{19}$ bahwa politik hukum dalam kajian studi ilmu hukum dapat ditemukan dalam studi ilmu hukum. Apabila kita menganalogikan pohon ilmiah hukum merupakan sebagai sebuah pohon, maka terdapat bagian-bagian pohon yang antara lain terdapat akar, pohon/batang. Dengan demikian terdapat cabang ilmu hukum, ranting ilmu hukum dan seterusnya. Secara konkrit maka dalam penjelasan studi hukum di Indonesia, pohon ilmiah hukum akan mencakup hal-hal berikut :

1. Pada pohon ilmiah ilmu hukum ideologi negara merupakan akar ilmu hukum. Akar ilmu hukum yang digunakan di Indonesia adalah dasar negara Pancasila dan Pembukaan UUD 1945. Kedudukan Pancasila dan UUD 1945 sebagai kaidah penuntun dalam menyusun perutauran perundang-undangan yang akan diberlakukan di Indonesia.

2. Setelah akar maka batang dari ilmu hukum antara lain psikologi sosial, antropologi, ekonomi, sosiologi, politik, sejarah, budaya, administrasi dan lain-lainnya, yang kemudian muncul cabang-cabang hukum. Berkaitan dengan hal tersebut maka muncul studi tentang sejarah hukum, sosiologi hukum, budaya hukum, politik hukum, psikologi hukum, administrasi hukum dan sebagainya yang semuanya menjadi bagian dari studi ilmu hukum.

Sosiologi membantu politik hukum dalam membuat kebijakan, dalam rangka pengendalian sosial (social control) dan perubahan sosial (social change) dalam masyarakat. Pergeseran nilai-nilai serta timbulnya nilai baru dalam masyarakat merupakan akibat dari perubahan dan pembaharuan. Jadi ilmu politik hukum dan sosiologi memiliki padangan yang sama terhadap negara namun politik hukum merupakan garis kebijakan negara berdasarkan tujuan negara sedangkan sosiologi merupakan stratifikasi sosial yang mempengaruhi kebijakan dalam rangka mewujudkan tujuan negara.

\footnotetext{
${ }^{17}$ Moh. Mahfud MD, Op. Cit, hlm.7

${ }^{18}$ Moh. Mahfud MD, Op.Cit, hlm. 7

${ }^{19}$ Moh. Mahfud MD, Op.Cit. hlm. 3
} 
Pada kajian sosiologi ketidakadilan berkaitan erat dengan stratifikasi sosial yang mendasarkan pada perbedaan tingkat pendapatan. Oleh karena itu antropolog dan sosiolog secara tipikal sebagai positivis dan/atau relativis. Artinya pengembangan analisis hak dan keadilan tidak dilakukan sehingga kajian sosiologis hanya mencakup ketidaksetaraan dan ketidakadilan berdasarkan ketimpangan pendapatan. ${ }^{20}$ Perbedaan penting antara sosiologi, politik dan hukum bahwa nilai keadilan dalam politik berkaitan dengan hak-hak akibat rezim politik sedangkan sosiologi berdiri sendiri tidak terikat antara keadilan dan hak.

Antropologi merupakan ilmu yang menpelajari tentang asal usul manusia, warna dan bentuk fisik manusia, adat istiadat dan kepercayaan masyarakat pada masa lalu. ${ }^{21}$ Gejala sosial di dalam masyarakat. Kesadaran berbangsa dan bernegara yang dipengaruhi ikatan primordial dibatasi pola-pola kesetiaan suku dan budaya begitu juga corak dan gaya kehidupan manusia. Politik hukum dan ilmu ekonomi merupakan ilmu yang berbeda namun ilmu ekonomi ini merupakan ilmu sosial yang digunakan pembangunan ekonomi. Kebijakan ekonomi yang digunakan untuk mencapai tujuan nasional yang modern. Dalam mengajukan kebijakan harus mempertimbangkan bidang ekonomi. Pesatnya perkembangan ilmu ekonomi maka perlu adanya kerjasama bidang politik hukum dan ilmu ekonomi. Hal ini karena makin dibutuhkan untuk mengalisis caracara dalam pembangunan nasional guna mencapai tujuan nasional negara Indonesia.

Psikologi sosial merupakan ilmu yang mempelajari hubungan timbal balik manusia di dalam masyarakat. Dalam psikologi sosial kepemimpinan tidak resmi (informal leadership) juga ikut menentukan kebijakan politik dan kenegaraan.

3. Batang dari ilmu hukum akhirnya muncul cabang-cabang ilmu hukum. Salah satu cabang dari ilmu hukum adalah hukum positif. Cabang dari ilmu hukum ini antara lain hukum tata negara, hukum administrasi negara, hukum perdata, hukum pidana, hukum adat, hukum islam, hukum dagang dan sebagainya. Sedangkan ranting-ranting ilmu hukum berkaitan dengan studi tentang Hukum Lembaga Negara, Hukum Lembaga Kepresidenan, Hukum Perundang-undangan dan sebagainya. Cabang Hukum Pidana melahirkan ranting studi tentang Hukum Pidana Khusus, Hukum Pidana umum, Hukum Acara Pidana dan sebagainya. Cabang hukum Perdata melahirkan ranting studi Hukum Asuransi, Hukum Keluarga, Hukum Perburuhan, Hukum Kontrak, Hukum Perbankan dan sebagainya. Cabang Hukum Administrasi Negara melahirkan ranting studinya dalam bentuk hukum kepegawaian, hukum pajak, hukum administrasi negara dan sebagainya.

Sedangkan berdasarkan skema Gerald M. Edelman ${ }^{22}$ dalam bukunya Bright Air, Brilliant Fire pada halaman 148 menjelaskan bahwa ada 2 lapisan, yang pertama kehidupan manusia berawal dari atom-atom yang membentuk molekulmolekul menjadi sebuah kumpulan yang disebut genetic code. Selanjutnya melalui seleksi alam (natural selection) molekul dan sel membentuk jaringan. Karena hukum tidak tertulis dibentuk oleh masyarakat, hukum tertulis dibentuk oleh legislatif dan hukum agama dibentuk oleh Tuhan. Hukum tidak dapat disebut ilmu karena hukum yang berasal dari gejala sosial yang timbul dari kehidupan manusia dalam masyarakat. Masyarakat yang terbentuk pasti menghendaki adanya ketertiban, keteraturan dan keadilan. Manusia sebagai makhluk sosial dalam kehidupannya sehari-hari melakukan interaksi sosial dengan manusia lain. Masing-masing manusia memiliki kepentingan yang berbeda yang pada akhirnya akan bertemu. Pertemuan kepentingan antara manusia yang satu dengan yang lain ini kadang akan menimbulkan persilisihan dan konflik yang berkepanjangan.. Gejala sosial dalam masyarakat kemudian dikaji supaya tujuan masyarakat tercapai, maka terbentuklah hukum. Pembentukan hukum dalam negara yang menganut common law tidak mendasarkan peraturan tertulis namun berdasarkan kebiasaaan dan keputusan hakim (judgemade law). Sedangkan negara yang menganut civil law mendasarkan pada peraturan perundang-undangan yang berlaku.

Studi ilmu hukum mencakup aspek-aspek di luar hukum positif. Hukum positif terdiri dari cabang dan ranting-ranting pohon ilmiah hukum. Politik hukum menjadi bagian kajian studi ilmu hukum, Berkaitan dengan pohon ilmiah hukum yang dimaksud maka kajian politik hukum pada bagian batang (pohon ilmu hukum). Ilmu hukum positif mengandung arti hukum yang berlaku pada masa sekarang. Ilmu hukum harus meliputi seluruh pohon ilmiahnya, seperti antropologi, filsafat, politik, sosiologi, administrasi negara, manajemen dan lain-lain. Cabang dan ranting ilmu hukum itu tak mungkin lepas dari akar dan batang pohon ilmu hukum. ${ }^{23}$

Dengan demikian menurut Gerald M. Edelman dalam pohon ilmu hukum ideologi dan pandangan hidup bangsa memiliki salah satu bagian tanaman dan tumbuh di dalam tanah yang merupakan fondasi dibentuknnya hukum. Akar memiliki fungsi utama yang digunakan untuk tumbuh. Demikian juga pada pembentukan hukum di Indonesia meliputi batang, cabang dan ranting ilmu hukum tersebut. Politik hukum merupakan merupakan salah satu kajian ilmu hukum.

Jika dikaitkan hubungan antara ilmu hukum dan ilmu politik dalam politik hukum maka:

1. Hukum determinan atas politik jika hukum dibentuk berdasarkan harapan atau apa yang seharusnya (das sollen);

2. Politik determinan atas hukum jika hukum dibentuk atas kesepakatan elite politik/kenyataan yang sebenarnya (das sein).

3. Hukum dan Politik interdependent/interdeterminant. Hukum dibentuk berdasarkan yang seharusnya/harapan dan kenyataan yang sebenarnya (das Sollen-Sein)

\footnotetext{
${ }^{20}$ Bryan S. Turner, Teori Sosial Dari Klasik Sampai Postmodern, 2012, Terjemahan oleh E.Setiawati A dan Roh Shulfiyati, Pustaka Pelajar, Jakarta, hlm xiii.

${ }^{21}$ Departemen Pendidikan Nasional, Kamus Besar Bahasa Indonesia, 2014, Cetakan Ketujuh Edisi IV, Gramedia, Jakarta, hlm. 77

${ }^{22}$ Gerald M. Edelman. Bright Air, Brilliant Fire. United States of Amerika: Basicbooks. 1992. hlm. 148

${ }^{23}$ Ibid hal 18.
} 


\section{IV.KESIMPULAN}

Politik hukum adalah kebijakan negara (garis resmi), yang konsep cakupan studi politik hukum di Indonesia meliputi, citacita bangsa Indonesia, tujuan negara Indonesia termaktub dalam Pembukaan UUD 1945 Alenia 4 yang merupakan bagian dari staatsfundamentalnorms. Hukum yang akan diberlakukan yang akan datang atau tidak diberlakukan dalam rangka mewujudkan tujuan negara dilatarbelakangi politik, perekonomian, sosial, budaya atau lahirnya produk hukum yang termuat dalam Prolegnas dan prolegda. Implementasi kebijakan hukum di lapangan diharapkan sebagai sarana untuk pembaharuan di dalam masyarakat. Namun jika hukum dibuat tidak mendasarkan nilai-nilai moral maka terbentuklah hukum yang kolutif, tidak bermoral dan tidak berkeadilan. Sebaliknya jika hukum yang dibuat mendasarkan nilai-nilai moral, berkeadilan dan dibuat oleh pejabat berwenang yang menjalankan fungsi dan kewajibannya maka terbentuklah hukum yang ideal yang sejalan dengan tujuan nasional negara.

Berkaitan dengan hal di atas maka ilmu politik hukum terhadap ilmu yang lain digambarkan pada pohon ilmiah hukum. Studi ilmu hukum itu mencakup banyak aspek di luar hukum positif. Hukum positif yang diberlakukan mencakup cabang dan rantingranting politik hukum. Ilmu politik hukum berada pada bagian batang (pohon) dari ilmu hukum. Oleh karena itu pandangan ilmu hukum merupakan hukum positif atau ilmu tentang hukum yang secara formal berlaku baiknya melihat sisi lain studi ilmu hukum yang merambah kuat dalam semua unsur pohon ilmiah seperti filsafat, politik, antropologi, sosiologi, administrasi negara dan sebagainya. Cabang dan ranting ilmu hukum akan selalu berkaitan akar dan batangnya.

Dengan demikian hubungan antara ilmu hukum dan ilmu politik bahwa hukum determinan atas politik jika hukum dibentuk berdasarkan harapan atau apa yang seharusnya (das sollen). Sebaliknya politik determinan atas hukum jika hukum dibentuk atas kesepakatan elite politik/kenyataan yang sebenarnya (das sein). Sedangkan hukum dan politik interdependent/interdeterminant jika hukum dibentuk berdasarkan yang seharusnya/harapan dan kenyataan yang sebenarnya (das Sollen-Sein).

\section{DAFTAR PUSTAKA}

Anderson, James E. Public Policy Makin.1984, Cetakan ke-3. New York : Holt Rinehart and Winston.

Asyhadie, Zaeni. 2014. Pengantar Ilmu Hukum. Jakarta : Rajagrafindo Persada.

Apeldoorn, Van. 2011. Pengantar Ilmu Hukum. Cetakan ke-34. Jakarta : Pradnya Praramita.

Budiardjo, Miriam. 2010. Dasar-dasar Ilmu Politik. Jakarta : Gramedia Pustaka Utama.

Departemen Pendidikan Nasional, 2014. Kamus Besar Bahasa Indonesia. (Cetakan Ketujuh Edisi IV). Jakarta : Gramedia.

Edelman : Gerald M. 1992. Bright Air, Brilliant Fire. United States of Amerika : Basicbooks.

Latif, Abdul, Op.cit.

Lawrence M, Friedmann. 2011. The Legal System : A Social Science Perspective (terjemahan oleh M Khozim) Bandung : Nusamedia.

Mahfud MD, Moh. 2010. Membangun Politik Hukum Menegakkan Konstitusi. Jakarta : Rajawali Pers. 2009. Konstitusi dan Hukum Dalam Kontroversi Isu. Jakarta : Rajawali Pres.

Mahfud MD, Moh. 2013. Perdebatan Hukum Tata Negara. Jakarta : Rajawali Pers.

Partodihardjo, Soemarno. 2009. Tentang Keterbukaan Informasi Publik. Jakarta : Gramedia.

Rahardjo, Satjipto. 2009. Hukum dan Perubahan Sosial (Suatu Tinjauan Teoritis Serta Pengalaman-pengalaman di Indonesia). Yogyakarta : Genta.

Rahman, Arief dkk. 2016. Pengantar Ilmu Hukum. Jakarta : Rajawali Pers.

Sampara, Said dkk. 2011. Buku Ajar Pengantar Ilmu Hukum. Yogyakarta : Total Media.

Syaukani, Imam dkk. 2004. Dasar-dasar Politik Hukum. Jakarta : Rajagrafindo Persada.

Turner, Bryan S. 2012. Teori Sosial Dari Klasik Sampai Postmodern. (Terjemahan oleh E.Setiawati A dan Roh Shulfiyati, Jakarta : Pustaka Pelajar. 